\title{
GROWTH, METABOLIC AND ADRENOCORTICAL EFFECTS OF SINGLE AND REPEATED ADMINISTRATION OF DIAZEPAM IN PIGLETS
}

\author{
M. DVOŘÁK \\ Veterinary Research Institute, 62132 Brno
}

Received March 27, 1980

\begin{abstract}
Dvořák M.: Growth, Metabolic and Adrenocortical Effects of Single and Repeated Administration of Diazepam in Piglets. Acta vet. Brno, 49, 1980: 177-186.

Diazepam was injected as a single $\mathrm{i} / \mathrm{m}$ dose to suckling piglets of two groups on the 2nd day after birth at 0.5 or $1.0 \mathrm{mg} / \mathrm{kg}$ body mass. In two other groups of pigs weaned at 4 weeks of age it was injected at $0.5 \mathrm{mg} / \mathrm{kg}$ body mass or fed for 14 days in feed medicated at $8 \mathrm{mg} / \mathrm{kg}$ after weaning. The tranquilizing effect was substantially more intense in newborn than in weaned piglets. A rise in relative liver mass was found only in newborn animals 2 hours after diazepam administration. The adrenocortical function of the experimental animals proved unaffected, but their plasma 11-hydroxycorticosteroid level showed a downward trend, compared to controls. Total plasma protein, glucose, urea, free fatty acid and cholesterol concentrations were not affected. The growth performance of piglets injected on the 2nd days after birth was"not impaired: their growth expressed in terms of total gain in body mass from birth to weaning was 6.8 per cent higher than that of their untreated littermates. Similarly, piglets fed diazepam-medicated feed at an average of $0.35 \mathrm{mg} / \mathrm{kg}$ body mass for 14 days after weaning gained 21 per cent more than the controls. Their feed consumption was practically the same as in the controls, but their feed conversion efficiency was better. Not all diazepam-medicated piglets showed signs of tranquilization. The alleviation of stress as suggested by blockade of the circulating corticosteroid increase during handling of the animals and the other results indicate the usefulness of diazepam as tranquilizer in pigs.
\end{abstract}

Tranquilization, stress, neonatal influences, development, pig.

A number of handlings of newborn animals have been reported to influence their further somatic development and function of some organs. These effects have been studied mainly in laboratory animals and some of them were confirmed in piglets (D vořák 1980). Similarly, drugs administered during the gestation and perinatal period may affect further development of the offspring. Besides adverse side-effect, they may have favourable sequelae. For example, phenobarbital was reported to stimulate the hepatic enzyme system metabolizing foreign substances in foetuses and young animals (Kuenzig et al. 1975).

Psychoactive drugs deserve attention also in view of their possible effects on postnatal neural development and later behaviour of the animals (Sparber 1972; Middaugh et al. 1975; Dörner 1976). Neonatal administration of chlorpromazine to mice increased endocrine and spermatogenic function of the testes (Hogarth and Chalmers 1973). On the other hand, diazepam treatment of rats cancelled the majority of late androgenic effects of neonatal stress (Erdösová et al. 1975).

Diazepam (7-chloro-1,3-dihydro-1-methyl-5-phenyl-2H-1,4-benzodiazepin-2-one) finds wide application in human medicine because of its anxiolytic, anticonvulsive and myorelaxant effects. It is also used in treating animals, particularly as tranquilizer administered to pigs before regrouping and transport (Drumew et al. 1972; Kolacz and Pejsak 1975; Dantzer 1977; Le istner 1978). In contrast to neuroleptics it has the advantage, together with other anxiolytics, that it can block, depending on dosage, the rise in plasma corticosteroid level occurring in stress ( $\mathrm{La} \mathrm{h}$ ti and 
Barsahn 1975). Given to piglets $\mathrm{i} / \mathrm{m}$ at $0.25 \mathrm{mg} / \mathrm{kg}$ body mass it did not induce eosinopenia characteristic of enhanced adrenocortical activity and showed good sedative effects as the animals were grasped and handled (Dvořák and Raszyk 1975).

The objectives of the present study were to elucidate the action of diazepam on adrenocortical function and selected parameters of substance metabolism and to assess the effects of its administration to newborn piglets, including its possible late effects on somatic development and other indicators at early weaning and after weaning. Moreover, relatively small doses of diazepam were given to weaned piglets for 14 days to study its effects on feed intake and utilization and its other pharmacological effects with the objective to assess the usefulness of its oral administration as a protection against the consequences of stress. Another objective was to find whether diazepam would exert different tranquilizing effects in newborn and weaned pigs.

\section{Materials and Methods}

Four groups of Large White piglets with approximately equal sex distribution reared in the Institute and weaned at 4 weeks of age on to a commercial prestarter (ČOS 1) and a starter (ČOS 2) were employed. All experimental treatments, blood collections from the cranial vena cava, weighing and exsanguinations by decapitation were carried out or started between 7 and 9 a.m. without previous food deprivation.

Group 1 comprised 8 experimental piglets and 7 controls from two litters. They were weighed on the second day after birth ( 32 to 36 hours after the farrowing was completed) and the experimental animals were injected $\mathrm{i} / \mathrm{m}$ with diazepam (Faustan, VEB Arzneimittelwerk, Dresden) at the rate of 0.5 or $1.0 \mathrm{mg} / \mathrm{kg}$. Two hours later all the animals were blood-sampled and killed.

Group 2 comprised 10 experimental weaned piglets and 8 control littermates aged 5 to 7 weeks. The experimental animals were treated $\mathrm{i} / \mathrm{m}$ with diazepam at the rate of $0.5 \mathrm{mg} / \mathrm{kg}$. All the animals were blood-sampled immediately before the start of the experiment and $11 / 2$ and 3 hours later and determinations were made of blood plasma 11-hydroxycorticosteroid (11-OHCS), glucose, free fatty acids (FFA) and total cholesterol concentration.

Group 3 comprised 19 experimental piglets and 19 control littermates selected from seven litters according to sex and body mass. On the 2nd day after birth the experimental animals were injected $\mathrm{i} / \mathrm{m}$ with diazepam at the rate of $0.5 \mathrm{mg} / \mathrm{kg}$ after all the animals were weighed and marked. The experimental and control animals were weighed at regular intervals and weaned at an average of 27 days of age. Two weeks later 11 animals of each group were exsanguinated. Blood examinations were made at weaning and 7 and 14 days after weaning.

Group 4 comprised 11 experimental piglets and 11 controls from 3 litters. After weaning at 28 to 29 days of age the experimental animals were fed for 14 days the commercial fed mixture medicated with diazepam at $8 \mathrm{mg} / \mathrm{kg}$ feed using crushed Diazepam SPOFA tablets in a flour premix, while the controls were fed the same feed without medication. Six animals of each group were exsanguinated at the end of the experiment.

In addition to checks on the clinical state and gain in body mass, determinations were made of blood plasma total protein, glucose, urea, FFA, total cholesterol and 11-OHCS. In exsanguinated piglets determinations were made of their actual and relative adrenal and liver mass and of the production of 17-hydroxycorticosteroids (17-OHCS) by adrenal tissue in vitro on incubation with adrenocorticotrophic hormone (ACTH). The methods used were described in a previous report (D vořák 1980). The results are tabulated as arithmetic means \pm standard deviations and shown graphically as means \pm standard errors of the means. The significance of the differences of the means was assessed by Student's t-test.

\section{Results}

The two different dose levels of diazepam given to newborn piglets of Group 1 resulted in almost the same clinical and laboratory findings. The animals fell asleep within $15 \mathrm{~min}$. of diazepam administration and remained lying under the heat lamp or scattered around the sow and did not awake when gripped or when their littermates were sucking. This state continued for nearly two hours, at the end of which the majority of piglets moved with a staggering gait, regardless of the dose level in one litter, but only after the diazepam dose of $0.5 \mathrm{mg} / \mathrm{kg}$ body mass in the other one. All the experimental animals were apathetic at exsanguina- 
tion. Since the mean plasma 11-OHCS level 2 hours after diazepam administration was $431 \mathrm{nmol} / 1$ in piglets given the drug at $1.0 \mathrm{mg} / \mathrm{kg}$ and $439 \mathrm{nmol} / 1$ in those treated at $0.5 \mathrm{mg} / \mathrm{kg}$ and since not even the values for the other criteria differed substantially between the two subgroups, the data for the two treatments were pooled. As compared to controls the administration of diazepam had no significant effect on any of the criteria under study except relative liver mass which was higher $(P<0.05)$ in the experimental piglets. On the other hand, the plasma 11-OHCS, urea and FFA concentrations of these animals showed a downward trend (Table 1).

Table 1

Body mass and parameters of adrenocortical function and substance metabolism in piglets two hours after i/m treatment with diazepam at 0.5 or $1.0 \mathrm{mg} / \mathrm{kg}$ on the 2 nd day after birth

\begin{tabular}{|c|c|c|}
\hline & Diazepam & Control \\
\hline $\begin{array}{l}\text { No. of piglets } \\
\text { Body mass }(\mathrm{kg})\end{array}$ & $\begin{array}{c}8 \\
1.50 \pm 0.30\end{array}$ & $\begin{array}{l}7 \\
1.51 \pm 0.32\end{array}$ \\
\hline $\begin{array}{l}\text { Liver mass } \\
\text { actual }(\mathrm{g}) \\
\text { relative }(\mathrm{g} / \mathrm{kg})\end{array}$ & $\begin{array}{l}41.4 \pm 9.9 \\
27.4 \pm 2.3\end{array}$ & $\begin{array}{l}38.4 \pm 8.7 \\
25.4 \pm 0.8 \text { a }\end{array}$ \\
\hline $\begin{array}{l}\text { Adrenal mass } \\
\text { actual }(\mathrm{mg}) \\
\text { relative }(\mathrm{mg} / \mathrm{kg})\end{array}$ & $\begin{array}{l}218 \pm 52 \\
147 \pm 29\end{array}$ & $\begin{array}{l}220 \pm 83 \\
145 \pm 31\end{array}$ \\
\hline $\begin{array}{l}\text { Production of } 17-\text { OHCS in vitro } \\
\text { ( } \mu \text { g per } 100 \mathrm{mg} \text { adrenal tissue) } \\
\text { Plasma 11-OHCS (nmol/1) } \\
\text { Total plasma protein }(\mathrm{g} / \mathrm{l}) \\
\text { Plasma glucose }(\mathrm{mmol} / \mathrm{l}) \\
\text { Plasma urea }(\mathrm{mmol} / \mathrm{l}) \\
\text { Plasma FFA }(\mu \mathrm{mol} / \mathrm{l}) \\
\text { Plasma cholesterol }(\mathrm{mmol} / \mathrm{l})\end{array}$ & $\begin{array}{c}14.7 \pm 1.8 \\
436 \pm 71 \\
58.1 \pm 7.0 \\
5.14 \pm 0.43 \\
7.25 \pm 1.79 \\
161 \pm 71 \\
1.95 \pm 0.48\end{array}$ & $\begin{aligned} & 14.8 \pm 1.7 \\
& 474 \pm 58 \\
& 54.8 \pm 9.8 \\
& 5.28 \pm 0.59 \\
& 7.82 \pm 2.49 \\
& 197 \pm 85 \\
& 1.92 \pm 0.44\end{aligned}$ \\
\hline
\end{tabular}

Difference between the means significant $(\mathbf{P}<0.05)$.

In Group 2 comprising weaned piglets the tranquilizing effect of diazepam at $0.5 \mathrm{mg} / \mathrm{kg}$ body mass was less pronounced than in newborn animals; nevertheless, it made itself felt at both $11 / 2$ and 3 hours after administration. If recumbent, the experimental animals regained their feet when touched and continued to eat. However, they could be seized quite easily and offered little resistance at blood collections. Their plasma 11-OHCS levels fell slightly by 3 hours after diazepam administration in contrast to the controls where the 11-OHCS value rose together with the FFA concentration by $1^{1 / 2}$ hours. However, the differences were not significant (Fig. 1). The blood glucose level underwent no change in either the experimental or control animals. The cholesterol level decreased from $2.78 \pm$ \pm 0.65 to $2.48 \pm 0.60 \mathrm{mmol} /$ in the experimental animals and from $2.68 \pm 0.65$ to $2.45 \pm 0.78 \mathrm{mmol} / 1$ in the controls.

Diazepam administration to newborn pigs of Group 3 produced no adverse late effects. On the contrary, the experimental piglets exhibited a better somatic growth and a higher total gain in body mass than the controls $(6.17 \pm 1.39$ vs. $5.75 \pm 1.78 \mathrm{~kg}$ ) during the suckling period. They gained faster than the controls from the first week of life till the third week. Afterwards their growth rate slowed down and they were less thrifty than the controls after weaning, at which time the body mass of the experimental and control piglets was approximately equal (Table 2). The 11-OHCS, FFA (Fig. 2), total protein, glucose, urea and cholesterol levels (Table 2) showed no significant differences between the experimental and control animals at either weaning or 7 and 14 days after weaning. A rise in 
Table 2

Parameters of growth, adrenocortical function and substance metabolism in six-week-old piglets injected $\mathrm{i} / \mathrm{m}$ with diazepam at $0.5 \mathrm{mg} / \mathrm{kg}$ on the second day after birth

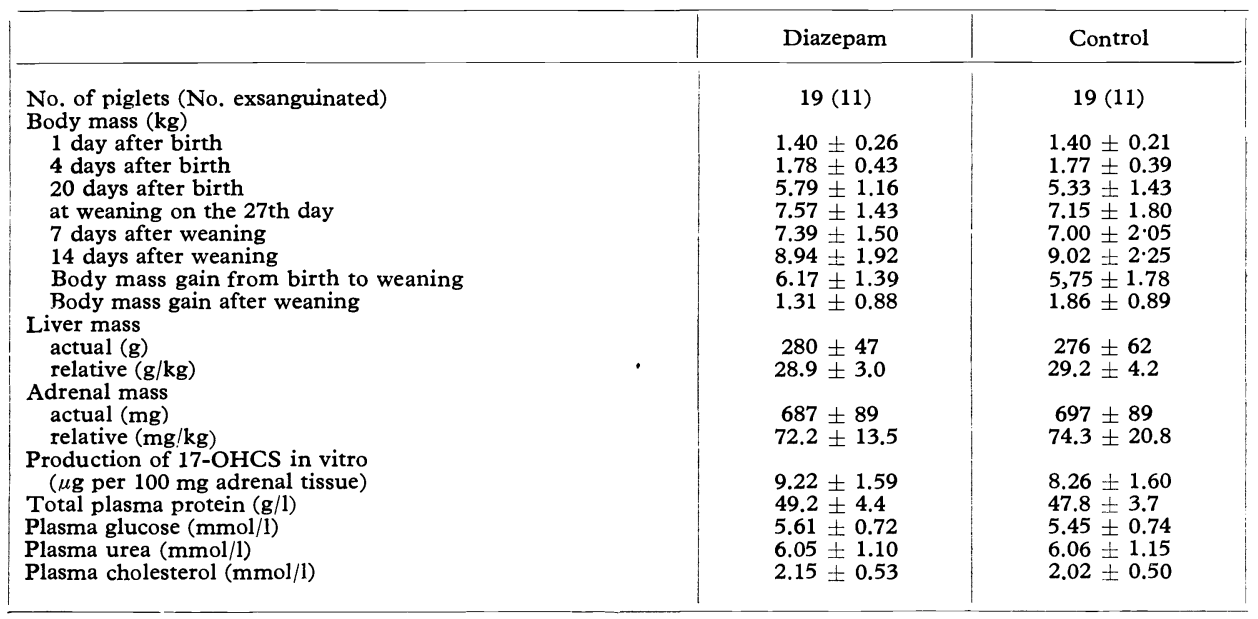
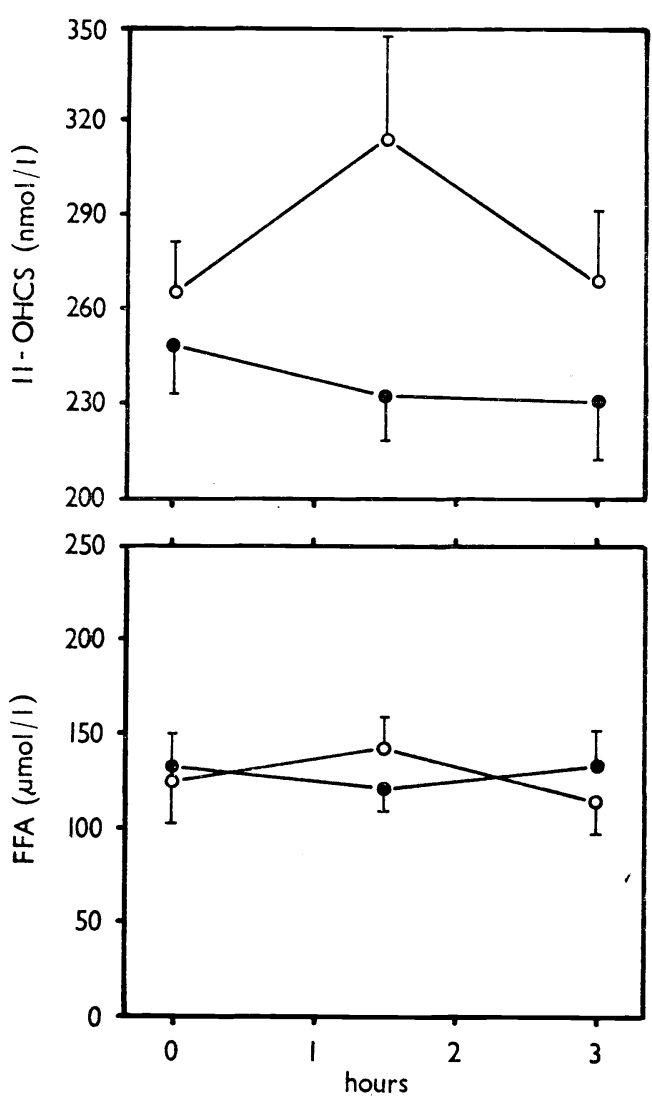

urea concentration $(P<0.01)$ and a fall in all the remaining indicators $(\mathrm{P}<0.05$ or 0.01$)$ were recorded in both the experimental and control animals at weaning time. In exsanguinated animals the liver mass, adrenal mass and the production of 17-OHCS by adrenal tissue in vitro also did not show significant differences between the experimental and control animals (Table 2).

Feeding of diazepam-medicated feed to weaned piglets of Group 4 for 14 days had a favourable, though not significant, effect on growth rate; the experimental animals gained $480 \mathrm{~g}$ more than the controls. Their body mass rose from $7.55 \pm 1.44$ to $9.78 \pm 1.40 \mathrm{~kg}$ against an increase from $7.51 \pm 1.74$ to $9.26 \pm 1.83 \mathrm{~kg}$ in the controls. The indicators of substance metabolism under study showed no significant differences

Fig. 1.

Levels of 11-hydroxycorticosteroids and free fatty acids in the blood plasma of weaned piglets after $\mathrm{i} / \mathrm{m}$ administration of diazepam at $0.5 \mathrm{mg} / \mathrm{kg}$ (closed circles), compared with untreated controls (open circles). 
between the experimental and control animals; at 14 days the glucose level was slightly higher $(5.11 \pm$ \pm 0.49 vs. $4.89 \pm 0.54 \mathrm{mmol} / \mathrm{l})$ and the urea level slightly lower $(6.14+$ \pm 0.95 vs. $6.45 \pm 0.92 \mathrm{mmol} / \mathrm{l})$ in the experimental animals than in the controls. The plasma 11-OHCS concentration, too, differed little between the experimental and control animals at the individual examinations; only its decline during the first postweaning days was somewhat deeper in the diazepam-fed animals (from $328 \pm 63$ to $232 \pm$ $\pm 36 \mathrm{nmol} / \mathrm{l})$ than in the controls (from $309 \pm 69$ to $235 \pm 38 \mathrm{nmol} / \mathrm{l}$ ). The relative adrenal and liver mass showed hardly any difference between the experimental and control animals, the production of 17-OHCS in vitro was lower in the diazepamfed animals $(10.9 \pm 3.8$ vs. $12.5 \pm$ $\pm 5.6 \mu \mathrm{g} / 100 \mathrm{mg}$ adrenal tissue). The feed consumption was approximately equal $(4.95 \mathrm{~kg}$ and $4.86 \mathrm{~kg}$ per animal during 14 days, respectively), but its utilization was better in the medicated animals (2.22 vs. $2.77 \mathrm{~kg} / \mathrm{kg}$ body mass gain). Sedative effects of diazepam added to the feed did not make themselves

felt in two litters where no distinct differences were observed in the behaviour of the animals either in pens or when grasped. In the third litter where pigs became restless after weaning the effects of the medication were apparent: the medicated animals were recumbent more frequently and offered less resistance when grasped. The mean daily intake of diazepam per animal was $3.0 \mathrm{mg}$, i.e. about $0.35 \mathrm{mg}$ per kg body mass.

\section{Discussion}

In view of the immediate pharmacological effect of diazepam it is noteworthy that the clinical manifestations of tranquilization in newborn piglets were substantially different than in older animals. Diazepam does not generally produce neuroleptic action; it failed to do so in pigs even a dose as high as $4 \mathrm{mg} / \mathrm{kg}$ (Drumew et al. 1972). Clinical manifestations of diazepam depend on its concentration in the blood and are particularly marked after intravenous administration, being manifested in man mainly by somnolence, unclear vision, amnesia and incoordination (Hillestad et al. 1974). With increasing diazepam doses its sedative effect rises more rapidly than the anxiolytic one (Wender et al. 1977). To tranquilize 
fallow-deer before treatment, diazepam-medicated feed was fed at a rate as high as $38 \mathrm{mg}$ diazepam $/ \mathrm{kg}$ body mass (Done et al. 1975). It can therefore be concluded that the effects of diazepam in newborn piglets in the present study were substantially greater than would correspond to the dose employed. Clinically, they were rather reminiscent of the comatose state described in rabbits, cats and rats with intoxication produced by diazepam doses of 80 to $120 \mathrm{mg} / \mathrm{kg}$ ( Nagy and Décsi 1978). A factor probably involved in the intensity of the effects is the drugmetabolizing hepatic enzyme activity which is low in piglets after birth (Short et al. 1972). Viewed in this light the enlargment of the liver after neonatal administration of diazepam seems to have been of toxic character rather than a result of mechanisms similar to hepatomegalic effects of phenobarbital that proved significant in weaned, but not in newborn piglets (Dvořák 1979b). It is apparently transitory and has no adverse consequences. Similarly, reserpine produced more intense and longer-acting effects in newborn than in adult rats (Bartolomé and Slotkin 1976).

Generally it can be argued that diazepam administration to piglets at a rate of $0.5 \mathrm{mg}$ per kg body mass on the second day after birth is sufficient to produce a state involving the CSN. This is corroborated by the data on the distribution of diazepam and its metabolites in the brain of cat and their affinity for thalamus, hypothalamus and hypophysis (Placidi et al. 1976). Studies focussed on positive effects of neonatal loads generally explained their action by changes in the responsiveness of the system regulating adrenocortical function (Levine 1960). Attempts were therefore made to demonstrate that loads used most frequently in rats during the neonatal period increase corticosterone secretion, thereby affecting the maturation of the hypothalamus (Denenberg et al. 1967). On the other hand, substances that suppress adrenocortical function may inhibit the effects of neonatal stimulation. With this in view it was demonstrated that $i / p$ injection of saline or ACTH into rats at 2 days of age increased their serum corticosterone levels, whereas diazepam injection cancelled the stress-producing action of the procedure associated with injection, since the serum corticosterone levels were below those found in the controls (Erdösová et al. 1975). Diazepam administered to four-day-old rats decreased their corticosterone concentration when given at a low level $(1 \mathrm{mg} / \mathrm{kg})$, but increased it when given at the rate of $10 \mathrm{mg} / \mathrm{kg}$ (Erdösová et al. 1977). In the present study, diazepam given to newborn piglets at 0.5 and $1.0 \mathrm{mg} / \mathrm{kg}$ reduced slightly their plasma $11-\mathrm{OHCS}$ level as compared with untreated controls. In weaned pigs the plasma 11-OHCS concentration was not changed by diazepam at $0.5 \mathrm{mg} / \mathrm{kg}$, but it showed a transient slight increase in the controls blood-sampled from the cranial vena cava in the same way. However, a large dose and a small dose of diazepam are rather relative terms as evident from the clinical manifestations in newborn piglets and from the effects of various benzodiazepines on the plasma corticosteroid level of stressed rats vhich was lowest at $8 \mathrm{mg} / \mathrm{kg}$ (Lahti and Bersuhn 1975).

The load of the neonatal organism with diazepam had no negative effects. On the contrary, diazepam-treated piglets had better growth performance than the controls from birth to weaning. Whether this was due to the neonatal stimulation or to the alleviation of the stress caused by concurrent handling of the piglets cannot be determined on the basis of the criteria under study. Young rats treated in a similar way also showed no significant differences in adrenocortical activity as against controls, yet their body mass was higher (Erdösová et al. 1975). It appears probable that neonatal administration of diazepam also exerts a direct ef- 
fect on the CNS and not only through cortisol. Moreover, the postnatal development of adrenocortical function in pigs is different from that found in rats (Dvoŕák 1972a) and the results of neonatal stimulation in these two species may not be the same.

The indicators of substance metabolism, too, showed hardly any differences between the experimental and control piglets. The changes recorded after weaning in Groups 3 and 4 were the same as those found in previous studies from our laboratory (Dvořák 1979a, b, 1980). The results of both single and prolonged diazepam administration suggest that under the conditions used the drug exerted no marked effect on the metabolism of the main nutrients. The transient rise of FFA level in Group 2 was induced by glucocorticoids or adrenaline (Dvořák 1979a) rather than by diazepam.

The intake of diazepam in feed at an average rate of $0.35 \mathrm{mg} / \mathrm{kg}$ during 14 days after weaning promote the gain in body mass. The suppressive effects on adrenocortical activity at days 7 and 14 were slight. At this time a decrease in both 17-OHCS and 11-OHCS levels is a common finding (Dvořák 1972a, 1980). This may be a favourable feature in relation to the glucocorticoid catabolic effects but at the same time an adverse one in relation to the defence of the organism against some noxae such as intoxications. However, the first postweaning days in pigs are accompanied by a state of stress with signs of enhanced adrenocortical activity (Dvořák 1972b) which, together with other changes and situations, may be an obstacle to successful weaning. One of them is a more or less intense psychic disturbance of the piglets. And it is in this sphere that tranquilizers may prove useful. In contrast to the data reported for rats and mice treated with a single dose of benzodiazepines (Soubrié et. al. 1975), the total feed consumption of the experimental piglets was not higher, but their feed efficiency was better than in the controls, similarly to the observations on phenobarbital intake (Dvorák 1979b). Another benzodiazepine, elfazepam, given to sheep was also reported to increase the digestibility of the feed (Krabill et al. 1978).

The growth-promoting effects of diazepam are to a certain extent contradicted by the finding that its sedative effects were not observed on prolonged administration in the majority of the animals. This, however, does not imply that its sedative action was nil. Apparently there are no substantial differences in diazepam effects between intramuscular and oral administration of the same doses (Hillestad et al. 1974). Other experiments on pigs showed that diazepam was more effective at 3 to $4 \mathrm{mg} / \mathrm{kg}$ than at $1 \mathrm{mg} / \mathrm{kg}$; animals given such high doses were mostly recumbent, apathetic and showed only little response when pricked with a needle (Drumew et al. 1972). However, lower diazepam doses are sufficient to produce sedation. One $\mathrm{mg}$ diazepam per $\mathrm{kg}$ body mass was recommended for tranquilization of pigs using a single oral dose of Relanimal (Polfa), a Polish product, but two doses of only $0.2 \mathrm{mg} / \mathrm{kg}$ were effective in reducing losses due to transport (Kolacz and Pejsak 1975). Distinct sedation was also observed after $\mathrm{i} / \mathrm{m}$ administration of diazepam at 0.15 a $0.25 \mathrm{mg} / \mathrm{kg}$ (Dvořák and Raszyk 1975). The aforementioned discrepancy can be explained by different metabolism of diazepam on chronic administration where its main metabolite, $\mathrm{N}$-desmethyldiazepam, present in the CSN antagonizes acute effects of diazepam so that its sedative and myorelaxant action is reduced (Placidi 1976). Added to this is the fact that food intake in the first days after weaning is less than in the second week and the quantity of ingested active ingredient was not always sufficient to induce distinct sedation. 
It can be concluded that diazepam is a promising drug for treatment of pigs in critical periods and situations, protecting the animals from the consequences of stress and facilitating their adaptation to new environmental conditions. From the practical point of view its neonatal administration as a growth-promoting tool is limited by an increased possibility of tranquilized piglets being lain upon and by undisclosed diazepam action on the liver parenchyma. It can be expected, however, that possible intake of diazepam or its metabolites with milk from medicated sows will not impair the development of their offspring.

\section{Růstové, metabolické a adrenokortikální účinky jednorázového a opakovaného podávání diazepamu selatům}

Ve čtyřech pokusech u sajících a časně odstavených selat byly zjištovány účinky a potenciální důsledky jednorázové intramuskulární aplikace diazepamu $\mathrm{v}$ dávce $0,5 \mathrm{mg} / \mathrm{kg}$ a jeho čtrnáctidenního př́imu s krmivem obsahujícím $8 \mathrm{mg} / \mathrm{kg}$. Trankvilizační účinek u novorozených selat byl podstatně silnější než u odstavených a jen u novorozených působil za 2 hodiny zvýšení relativní hmotnosti jater. Nebylo prokázáno působení na funkci kůry nadledvin, hladina plasmatických 11-hydroxykortikosteroidů však jevila ve srovnání s kontrolami trend ke snížení. Nebylo zjištěno ovlivnění koncentrace celkového proteinu, glukosy, močoviny, neesterifikovaných mastných kyselin ani cholesterolu krevní plasmy. Parenterální aplikace selatům druhý den po narození nezanechala nepríiznivé důsledky; jejich růst, vyjádřený celkovým přírůstkem tělesné hmotnosti, byl do odstavu o 6,8\% lepší než u neošetřených sourozenců. Podobně o $21 \%$ byl růst lepší u selat, která během 14 dní po odstavu od prasnice přijímala $\mathrm{s}$ krmivem $\mathrm{v}$ prưměru $0,35 \mathrm{mg}$ diazepamu na kg tělesné hmotnosti. Spotřebou krmiva se nelišila, jeho využitelnost však byla větší než u kontrol. Při této medikaci se sedativní účinek diazepamu u všech selat zřetelně neprojevoval. Naznačené tlumení stresového stavu blokováním zvýšení hladiny cirkulujících kortikosteroidů při manipulaci s pokusnými selaty i další působení svědčí pro použitelnost diazepamu $\mathrm{k}$ trankvilizaci prasat.

\section{Ростовсе, метаболическое и адренокортикальное действие единократной и повторной подачи диазепама поросятам}

В ходе четырех опытов с молочными поросятами и преждевременно отнятыми поросятами выявлялось действие и возможные последствия единократного внутримышечного применения диазепама дозой $0,5 \mathrm{mr} /$ кг и его двухнедельного приема с кормом, содержащим 8 мг/кг. Успокаивающее действие у новорожденных поросят выразилось более существенно, чем у отьемных, и лишь у новорожденных он стал причиной увеличения относительного веса печени в течение 2 часов. Воздействие на функщию коры надпоченных желез не было установлено, уровень плазматических 11-гидроксикортикостероидов, однако, по сравнению с контрольной группой отличался тенденцией к понижению. Не было установлено влияние конщентрации общего протеина, глюкозы, мочевины, неэстерифицированных жирных кислот, ни холестерина кровяной плазмы. Парентеральное применение поросятам на второй день после опороса не сопровождалось неблагоприятными последствиями; их рост, выраженный в общем приросте веса, до отьема стал на 6,8 \% лучше кон- 
трольной группы. Подобным образом, рост у поросят, принимавших в течение двух недель после отъема с кормама в среднем 0,35 мг диазепама на кг живого веса, стал на $21 \%$ лучше. Расходом кормов не отличались, однако, по сравнению с контрольной группой, их используемость была лучше. В ходе использования указанного препарата успокоительное воздействие выявлялось не у всех поросят одинаковым способом. Отмеченное торможение стрессов блокировкой повышения циркулирующих кортикостероидов в ходе обращения с подопытными поросятами и другие виды воздействия свидетельствуют о применимости диазепама с целью успокоения поросят.

\section{References}

BARTOLOMÉ, J. - SLOTKIN, T. A.: Effects of postnatal reserpine administration on sympatho-adrenal development in the rat. Biochem. Pharmac., 25, 1976: 1513-1519.

DANTZER, R.: New aspects of the use of tranquillizers in animal husbandry, with particular reference to pigs. Vet. Sci. Commun., 1, 1977: 161-169.

DENENBERG, V. H. - BRUMAGHIM, J. T. - HALTMEYER, G. C. - ZARROW, M. X.: Increased adrenocortical activity in the neonatal rat following handling. Endocrinology, 81, 1967: $1047-1052$.

DONE, S. H. - LEES, P. - DANSIE, O. - WATKINS, L. W.: Sedation and restraint of fallow deer with diazepam. Br. vet. J., 131, 1975: 545-548.

DÖRNER, G.: Further evidence of permanent behavioural changes in rats treated neonatally with neurodrugs. Endokrinologie, 68, 1976: $345-348$.

DRUMEW, D. - GEORGIEW, B. - KOITSCHEW, K. - DILOW, P. - MENDOW, C.: Die Wirkung von Diazepam (Faustan) bei landwirtschaftlichen Nutztieren. Mh. Vet. Med., 27, 1972: 615-621.

DVOŔ̆K, M.: Adrenocortical function in foetal, neonatal and young pigs. J. Endocr., 54, 1972a: $473-481$.

DVOŘÁK, M.: Aktivita kůry nadledvin při odstavu selat ve srovnání se stimulací exogenním ACTH. Vet. Med., Praha, 17, 1972b: 671-678.

DVOKÁK, M.: Účinky odlišného růstu odstavených selat, hladovění a hormonálního působení na některé metabolické parametry v krevní plazmǒ. Vet. Med., Praha, 24, 1979a: 301-310.

DVOŘ́́K, M.: Effect of phenobarbital on growth, adrenocortical activity and some metabolic parameters in piglets. Acta vet., Brno, 48 1979b: 67-77.

DVOŘ́K, M.: Vývoj selat po neonatální vénepunkci nebo orchidektomii. Vet. Med., Praha, $25,198011-19$.

DVOǨÁK, M. - RASZYK, J.: Účinek některých psychofarmak na hematologickou stressovou odpověd' u selat. Vet. Med., Praha, 20, 1975: 689-699.

ERDÖSOVÁ, R. - JAKOUBEK, B. - KRAUS, M.: Effect of stress and diazepam treatment during infancy on corticosterone regulation and androgenic activity in adult male rats. Experientia, 31, 1975: 62 .

ERDÖSOVÁ, R. - KRAUS, M. - ̌̌EHULKA, J.: Influence of stress and phenobarbital on corticosterone metabolism during early postnatal life of rat. Life Sci., 20, 1977: 459-466.

HILLESTAD, L. - HANSEN, T. - PHARM, B. - MELSOM, H. - DRIVENES, A.: Diazepam metabolism in normal man 1 . Serum concentrations and clinical effects after intravenous, intramuscular, and oral administration. Clin. Pharmac. Ther., 16, 1974: 479-484.

HOGARTH, P. J. - CHALMERS, P.: Effect of the neonatal administration of a single dose of chlorpromazine on the subsequent sexual development of male mice. J. Reprod. Fert., 34, 1973: $539-541$.

KOLACZ, R. - PEJSAK, Z.: Zapobieganie stresom w warunkach przemysłowych technologii tuczu trzody chlewnej za pomoca preparatu Relanimal. Zycie wet., 50, 1975: 228-230.

KRABILL, L. F. - WANGSNESS, P. J. - BAILE, C. A.: Effects of elfazepam on digestibility and feeding behavior in sheep. J. Anim. Sci., 46, 1978: 1356-1359.

KUENZIG, W. - KAMM, J. J. - BOUBLIK, M. - BURNS, J. J.: The effect of phenobarbital on the microsomal mixed-function oxidase system and hepatic ultrastructure in the perinatal guineas pig. In: Basic and therapeutic aspects of perinatal pharmacology. Ed. Morselli P. L., Garattini S., Sereni F., New York, 1975, pp. 289-300.

LAHTI, R. A. - BARSUHN, C.: The effect of various doses of minor tranquilizers on plasma corticosteroids in stressed rats. Res. Commun. chem. Path. Pharmacol., 11, 1975: 595-603. 
LEISTNER, W.: Möglichkeiten des Einsatzes von Tranquilizern bei Schlachtschweinen während ihres Transports. Fleisch., 32, 1978: 97-98.

LEVINE, S.: Stimulation in infancy. Scient. Am., 202, 1960: 80-86.

MIDDAUGH, L. D. - SANTOS, C. A. - ZEMP, J. W.: Effects of phenobarbital given to pregnant mice on behavior of mature offspring. Devl. Psychobiol., 8, 1975: 305-313.

NAGY, J. - DECSI, L.: Physostigmine, a highly potent antidote for acute experimental diazepam intoxication. Neuropharmacology, 17, 1978: 469-475.

PLACIDI, G. F. - TOGNONI, G. - PACIFICI, G. M. - CASSANO, G. B. - MORSELLI, P. L.: Regional distribution of diazepam and its metabolites in the brain of cat after chronic treatment. Psychopharmacology, 48, 1976: 133-137.

SHORT, C. R. - MAINES, M. D. - WESTFALL, B. A.: Postnatal development of drug-metabolizing enzyme activity in liver and extrahepatic tissues in swine. Biol. Neonate, 21, 1972: $54-68$.

SOUBRIÉ, P. - KULKARNI, S. - SIMON, P. - BOISSIER, J. R.: Effets des anxiollyti-: ques sur la prise de nourriture de rats et de souris placés en situation nouvelle ou familière. Psychopharmacologia, Berlin, 45, 1975: 203-210.

SPARBER, S. B.: Effects of drugs on the biochemical and behavioral responses of developing organisms. Fedn Proc., 31, 1972: 74-80.

WENDER, R. H. - CONNER, J. T. - BELLVILLE, J. W. - SCHEHL, D. - DOREY, F. - KATZ, R. L.: Comparison of i.v. diazepam and hydroxyzine as surgical premedicants. Br. J. Anaesth., 49, 1977: 907-912. 